\title{
Asynchronous Backtracking Algorithm For Analysis Of Financial Performance Multiagent System
}

\author{
Mahrus Ali ${ }^{1, *}$, Oky Dwi Nurhayati ${ }^{2}$, And Jatmiko Endro Suseno ${ }^{3}$ \\ ${ }^{1}$ Magister Program of Information System, School of Postgraduate Studies, Diponegoro University, Semarang - Indonesia \\ ${ }^{2}$ Department of Environmental Engineering, Faculty of Engineering, Diponegoro University, Semarang - Indonesia \\ ${ }^{3}$ Department of Physics, Faculty of Science and Mathematics, Diponegoro University, Semarang - Indonesia
}

\begin{abstract}
This study describes the prediction of a financial performance of educational institutions, especially the Multi-agency based. That is one educational institution that has several educational institutions under it. To measure the prediction of the financial performance, the researchers integrate the concept of multiagent system and asyncronuos backtracking algorithm whose function is to look back on the processes of activities in each institution in terms of finance, and then compared from one institution to another. The workings of this algorithm is to calculate some of the result variables from the calculations of each institution. So what will be the best educational institution will appear as the end result or ouput from this research.
\end{abstract}

Keywords: Asynchronous Backtracking; Multiagent system; Financial Performance.

\section{Introduction}

The professionalism of an institution can be measured, one of which is from the implementation of financial management. Financial administration in an organization is a function that involves the process of recording all financial transactions both from those entering and leaving in a certain period. Financial administration recording period can be made periodically starting from daily, weekly, monthly, quarterly, and yearly[5].

In the economic perspective, measuring financial performance, there are several types of methods, namely Market Value Added (MVA), Earnings Per Share (EPS), Return On Investment (ROI) for measure net income and Economic Value Added (EVA). with several types, namely Liquidity Ratio, Financial Leverage Ratio, Profitability Ratio, Activity Ratio. Of course with some of the above methods to measure the financial performance of a company or agency has weaknesses and strengths[6][7].

The backtracking algorithm aims at avoiding the generation of all possible solutions, thereby cutting short the calculation time. [1][8].

Multiagent system is the task of modeling and calculation becomes a lot more complex because of its increasing size. Then the results from that are very tiring and difficult to handle using a centralized method[9]. Although the motivation to implement Multiagent System (MAS) researchers from a variety of different disciplines, [4], the main advantages of using multi-agent technology are: (1) individuals take into account the specific nature and environment of the application; (2) local interactions between individuals can be modeled and investigated; and (3) difficulties in modeling and calculation are arranged as sub-layers and / or components.

Dwija Bhakti has more than one vocational high school. Where management starts paying students until spending is carried out centrally, but the Foundation has problems related to monitoring and evaluation related to the development of the Education unit, especially in the financial sector of each education unit.

the researcher starts to make research related to multiagent system-based financial management with the process of solving it by using the asyncronous backtracking algorithm, which is expected to be able to complete related monitoring and evaluation in the form of financial performance in each institution along with a solution offer after calculation of the acyncronous backtracking algorithm.

\section{Research Methode}

As for this research approach using a method which is divided into three processes, namely Data Collection, Pre-Processing Data, and Data Processing. The data is processed manually or by using Excel as the material for testing the truth of the data and the theory that has 
been synchronized after that is implemented in the construction of the system. The purpose of this study was to look at the measurement of financial performance of educational institutions based on multi-systems using the ABT approach. Asyncronous Backtracking it self is a computational approach, which is based on building a state-space tree to find solutions [2]. For more details, the algorithm will be explained as shown below[2].

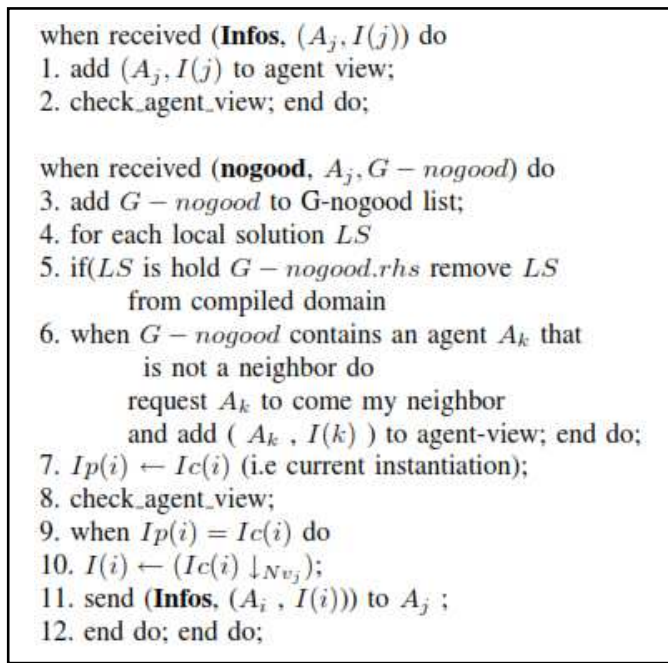

Fig. 1. algorithm when there is good information and messages from $\mathrm{ABT}$ run by agent $\mathrm{X}$

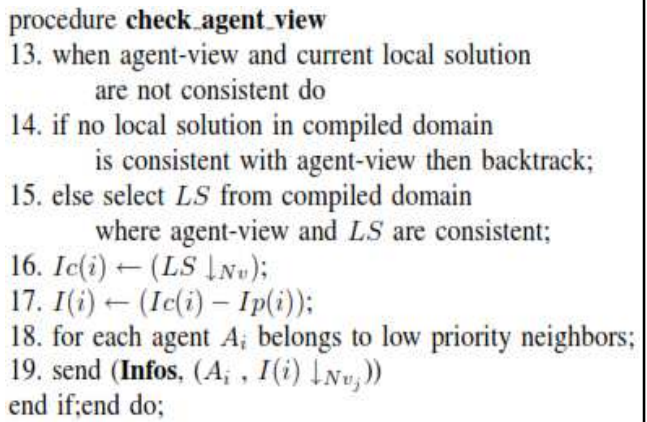

Fig. 2. ABT agent procedure that is run by an artificial intelligence agent

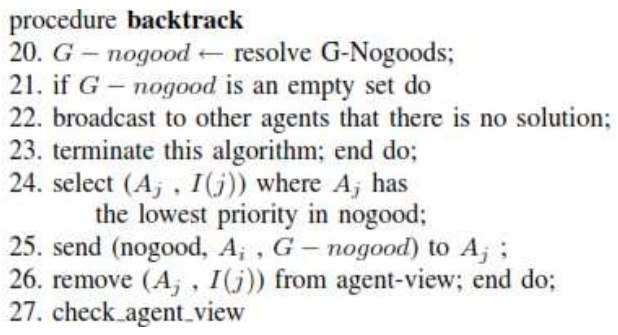

Fig. 3. The procedure of $A B T$ is run by an Artificial intelligence agent

\subsection{Data Collection}

As for the acquisition of processed data for the sustainability of this research is historical data fromfinancial reports of the Dwija Bhakti educational foundation under which there are two educational unit institutions from jombang. The numerical data used was taken from the 2009 period until 2010 from the two units of educational institutions. Total data collectedis 40744 transactions from all types of student payments for student payments (Income) and the total of expenditure transactions is 971. with a total of 2,227 student master data, consisting of 1,171 students from the dwija bhakti 1 educational unit and 1,056 students from the dwija bhakti educational unit 2 .

\subsection{Pre-Processing}

The financial data from the dwija bhakti jombang education foundation has been filtered and classified according to the name of the type of income from each financial report in the form of a processed data table. Figures and variations of the variables that have been determined are based on the economic theory that has been carried out by previous research related to the financial performance of the institution. first calculate each variable that is known to obtain the final value that can later calculate EVA. The number of variables used by more than 10 variables is as follows:

VPS = Payment From Student (Payment From Student)

VGC $=$ Government Cost Assistance

$\mathrm{VNP}=$ Net Profit

VWACC $=$ Weighted Average Cost of Capital

$\mathrm{VCD}=$ Cost of debt after tax.

$\mathrm{VOC}=$ own cost of capital

$\mathrm{VPD}=$ proportion of debt.

$\mathrm{VPC}=$ proportion of debt

$\mathrm{VNT}=$ Net profit after tax

VPL $=$ Profit and Loss (profit and loss)

\subsection{Data Processing}

This study uses the Economic value added (EVA) method to find financial performance for each agent or institution, then look for which agent is the best by using multi-system-based Asyncronous backtracking method as well as calculation steps from EVA to Asyncronous backtracking system and multiagent system based as follows:[3]

There are several steps that must be taken in the calculation of EVA as follows:

1. Calculating net income after tax or Net Operating After Tax (NOPAT).

2. Calculating capital invested in total or Invested Capital (IC).

3. Determine a capital cost or Weighted Average Cost of Capital (WACC).

4. Calculating EVA $=$ NOPAT $-($ WACC $*$ IC $)$.

The iteration steps of the formula are as follows:

a) Calculating NOPAT with the Formula:

NOPAT $=$ Earning After Tax + Interest Fee 
b) Calculate IC Value with formula.

$$
I C=\text { Total Debt and equity }- \text { Short Term }
$$

Equity: Owner's rights to company assets which are net assets (total assets less liabilities).

c) Calculate of WACC with the formula:

$$
W A C C=(D * r d(1-\operatorname{tax}))+(E * r e)
$$

Information:

D : Calculating the level of capital, as for the formula as follows:

$$
\begin{gathered}
\text { Rr } D=\frac{\text { Debt Total }}{\text { Debt Total dan Equity }}: 100 \% \\
\text { rd }=\frac{\text { interest expense }}{\text { Debt Total }}: 100 \% \\
\operatorname{Tax}=\frac{\text { Beban pajak }}{\text { Laba Sobelum pajak }}: 100 \%
\end{gathered}
$$

Re : Cost of equity, as for the formula as follows:

$$
r e=\frac{1}{P E R} \times 100 \%
$$

PER : Price to Earning

E: Capital level of equity, as for the formula as follows.

$E=\frac{\text { total of equity }}{\text { Debt and Equity Total }} * 100 \%$

EVA (Economic Value Added) Benchmarks :

(1) If EVA $>0$, then the company added value process.

(2) If $\mathrm{EVA}=0$, indicates the company's or institution is break even position.

(3) If EVA $<0$, meaning that the total cost of capital of a company or institution is greater than the operating profit after tax is obtained. So that the financial performance of the company or institution is not good [9].

after calculating the financial performance of each agency or agent then look for the best performance

\begin{tabular}{|c|c|c|}
\hline \multirow{2}{*}{$\begin{array}{l}\text { School } \\
\text { year }\end{array}$} & \multicolumn{2}{|c|}{ Total Revenue of each education unit } \\
\hline & $\begin{array}{l}\text { Dwija Bhakti } 1 \\
\text { (1324 student) }\end{array}$ & $\begin{array}{l}\text { Dwija Bhakti } 2 \\
\text { (1193 student) }\end{array}$ \\
\hline $\begin{array}{l}\text { Juli 2009/ } \\
\text { Juni } 2010\end{array}$ & Rp. 1.726.605.000,- & $R p .1 .617 .59$ \\
\hline
\end{tabular}
using the asyncrhonous backtracking algorithm.

\section{Result And Analysis}

From the results of manual and computational calculations, the following values are obtained.

Table 1. income of each institution after a performance test is conducted related to income from each education unit, it is actualized in the graph as below.

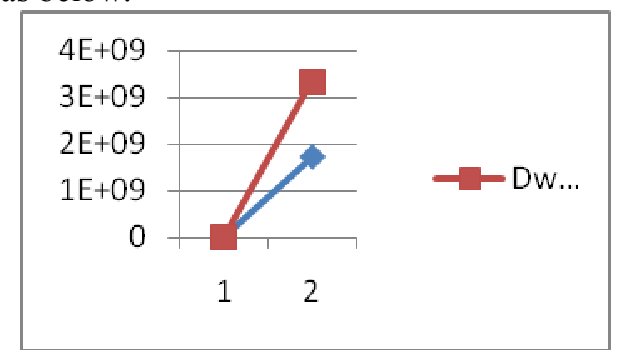

Fig. 4. Caption Of performance income graph

the results of the Asynchronous backtracking algorithm test then obtained the graph as below and While communication between agents is shown in the graph as below.

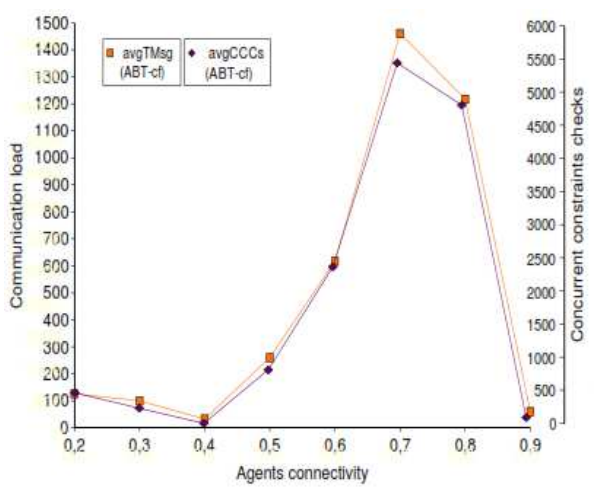

Fig. 5. Communication load and average run-time performed

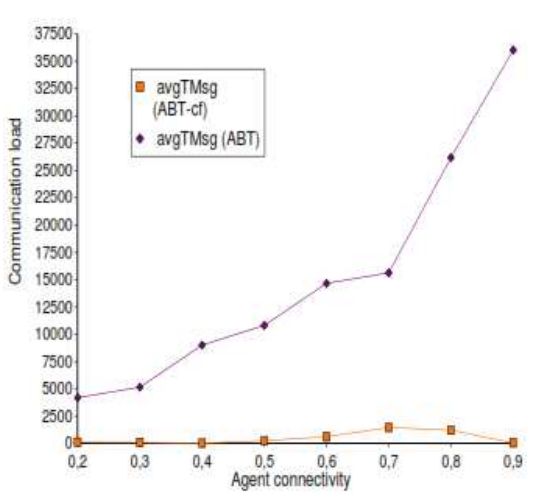

Fig. 6. Number of messages sent from dwija bhakti 2 to Dwija bhakti 1 


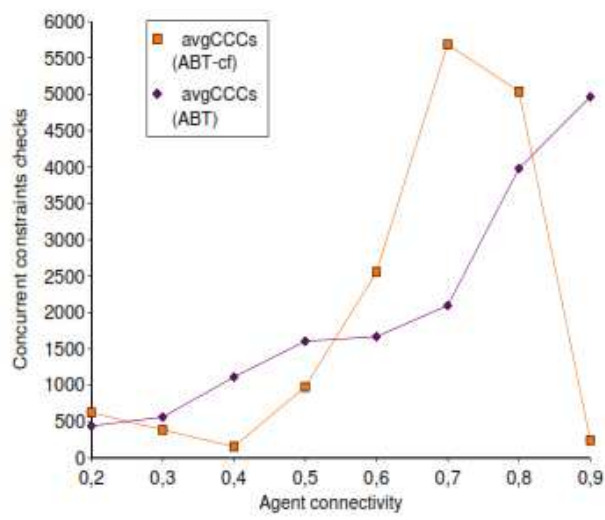

Fig. 7. Number of concurrent constraints Dwija Bhakti 1 and Dwija Bhakti 2

when in the performance measurement of multi agents, there are messages sent from several agents who need financial resources support. because between inputs and outputs from the use of financial agents are not balanced. In this case, dwija bhakti 2 often sends a message to dwija bhakti 1 which is legally legible dwija bhakti 1 has met the criteria for good financial performance. the difference from dwija bhakti 1 and dwija bhakti 2 is located in the contribution of educational assistance. Dwija Bhakti 1 is superior to $20 \%$ of Dwija Bhakti 2. Communication of some of these agents is systemic and automatic without user intervention when some agents need financial resource support

\section{Conclution}

In this study, it can be concluded that the financial performance of the revenue section, dwija bhakti 1 is much better than Dwija Bhakti 2, but the financial performance with Dwija Bhakti 2's expenditure section is much better than Dwija Bhakti 1. on the algorithm testing shown in the graph as below.

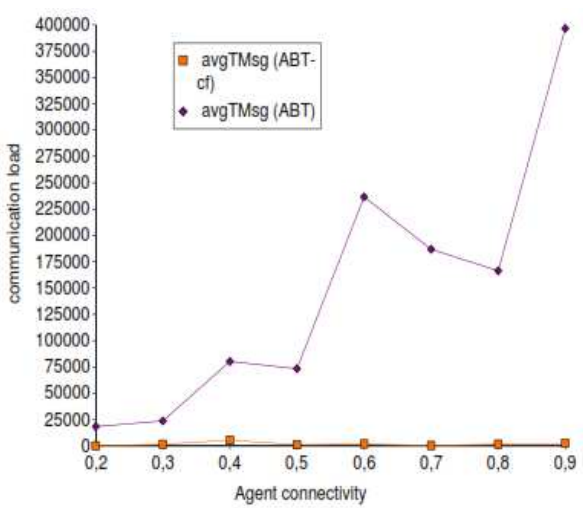

Fig. 8. the process of sending data (messages) based on the amount

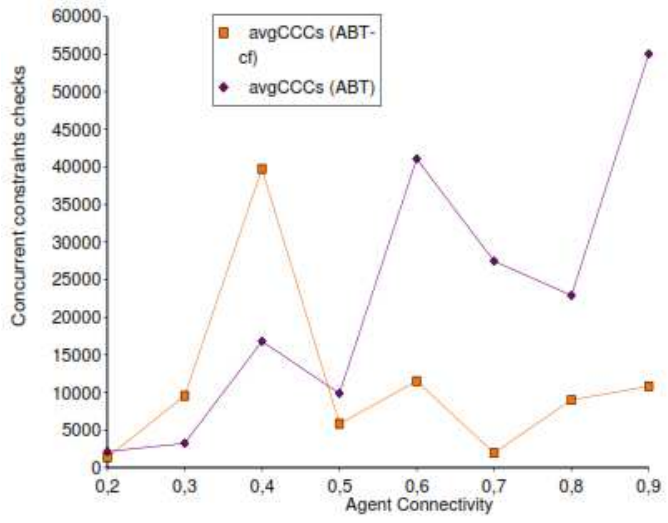

Fig. 9. constraints checks performed by ABT

the results of this study, it is very appropriate to implement in an institution or company that has several educational or business units under it. because the measurement of multi-institution performance using this application can be known. and can make new policies that are more progressive based on measured performance such as the Dwi Bhakti Foundation, this foundation can finally determine a better future policy

\section{References}

1. Claudiu, F. Romanian journal of information Science and technology 13. Number 3, 241-254.( 2010).

2. Ezzahir, R,. Mustapha, B,. Christian, B,. El Houssine, B. ISCIII. IEEE. 1-4244-1158-0/07 (C)2007.

3. Md. Shafiullah,. M. A. Abido,. L. S. Coelho. 9781-5090-0191-0/15/ (C2015 IEEE.

4. Jing Xie. and Chen-Ching Liu. ICCIl on CICal, Vol. 7 no. 1, 188-197. 2017.

5. Luciano, R. Lucas, R. Elsevier .0961-9534/ (C) 2017.

6. Ling, L,. Yanxi, L, Kejing Chen 978-1-47991014-4/13/\$31.00 (2013 IEEE

7. Nurul Aisyiah. Darminto. Achmad Husaini. (JAB)|Vol. 2 No. 1 Mei 2013.

8. Mohammad, S.S,. Md. Shafiullah,. Mohammed Afzal Asif. Md. Mahmudul Hasan. Md. Rafiuzzaman. ICCIIT) 21-23 desember 2015.

9. Sawir, A. Analisis Kinerja Keuangan dan Perencanaan Keuangan Perusahaan. PT Gramedia Pustaka Utama. Jakarta. 2001. 